\title{
Youth Empowerment Scheme And Poverty Status Of Youth In Oyo State, Nigeria.
}

\author{
Inyang, N. D. ${ }^{\mathrm{a}}$, Okijie, S. R. ${ }^{\mathrm{b}}$ and Asa, U. A. ${ }^{\mathrm{c}}$ \\ a nsonuruaetuk@gmail.com \\ ${ }^{\text {a,c }}$ Department of Agricultural Economics and Extension, University of Uyo, Uyo, Akwa Ibom State, Nigeria. \\ ${ }^{\mathrm{b}}$ Department of Sociology and Anthropology, University of Uyo, Uyo, Akwa Ibom State, Nigeria.
}

\begin{abstract}
The study revealed the effect of Youth Empowerment Scheme on the poverty status of youth in Oyo State. Data for the study were obtained from ninety youth participants and non-participants of the scheme using multi-stage and snowball sampling techniques. The data were analyzed using descriptive statistics and test of difference. Results indicated that the average age of participants in the scheme was 29 years and $53.9 \%$ of the respondents were female. $51.7 \%$ of the respondents were married and $91.6 \%$ were functionally literate. Findings also revealed that the poverty status of youth in the study area is moderate due to the fact that majority $(60.6 \%)$ of the respondents fall within the "average" category. The result of the test of difference showed that there is no significant difference between the poverty status of participants and non-participants of the Youth Empowerment Scheme ( $t=0.99$ and $p=0.182)$. By implication, Youth Empowerment Scheme did not improve the poverty status of youth in the study area. Therefore, efforts should be made to realign the programme's objectives through proper monitoring and evaluation at every stage to take corrective measures and improve on the programme.
\end{abstract}

Keywords: Youth Empowerment Scheme; poverty status.

\section{INTRODUCTION}

The scourge of poverty has ravaged almost all nations of the world in different dimensions and shades; it has become a serious social problem and tops Nigeria's list of policy priorities. Despite Nigeria's endowment with oil and natural resources, a substantial portion of its population remains very poor (Canagarajah and Thomas, 2002). Mazharul and John (2012) stated that as Nigeria's economy is expected to grow, and as the gap between rich and poor continues to widen, poverty may worsen. Poverty shows a situation of deprivation in which individual or groups in society lack the resources, opportunities or means of survival to lead a long, healthy, and satisfying life because they cannot meet their basic life needs, such as water, food, shelter, clothing, sanitation and a minimum level of medication (Onuoha, 2007). Poverty in Nigeria greatly affects the youth because of their vulnerability due to age and dependency, among other challenges (Etuk, 2015). These other challenges include socioeconomic status, living arrangements, personal relationships and employment (Okafor, 2011). Youth poverty is not only dehumanizing, it also poses a serious threat to the economic, social, political and environmental stability of Nigeria. The Federal Government of Nigeria, over the years, has introduced poverty alleviation programmes such as Operation Feed the Nation (OFN), Directorate of Food, Roads and Rural Infrastructure (DFRRI), National Directorate of Employment (NDE), Better Life Programme (BLP), Family Support Programme (FSP), National Poverty Eradication Programme (NAPEP) to ameliorate poverty, yet there still exists a high incidence of youth poverty in the country due to the failure of these programmes to achieve their stated objectives as well as the programmes not being specifically targeted at youth in the various states of the country (Asa, Ekumankama, Ebong and Uwem, 2007). The Youth Empowerment Scheme of Oyo State (YES-O) was introduced in 2011 by the Government of Oyo State in Nigeria to specifically address the high incidence of poverty among youth in the State. The scheme has been in operation since then. This paper, therefore, aims to reveal whether the scheme has achieved its major goal of poverty reduction among the youth in Oyo State. Specifically, the objectives of the paper are to:

- describe the socio-economic characteristics of youth in the study area,

- determine the poverty status of participants and non-participants of Youth Empowerment Scheme in the study area, and 
- compare the poverty status of youth who participate in the Youth Empowerment Scheme and youth who are non-participants of the scheme.

\section{METHODOLOGY}

\subsection{Study Area}

The study was conducted in Oyo State which is located in the south west region of Nigeria between latitude $7^{0} 02^{\text {" }} \mathrm{N}$ and $9^{0} 10^{\prime \prime} \mathrm{N}$ and longitude $2^{0} 04^{\prime \prime} \mathrm{E}$ and $4^{0} 30^{\circ} \mathrm{E}$. The state is bounded in the north by Kwara State; and in the west partly by Ogun State and partly by the Republic of Benin. The total population of Oyo State is 5,591,589, including 2,809840 males and 2,781,749 females (National Population Census, 2006). The area is mainly inhabited by the Yoruba agricultural ethnic group which is a typical feature of many rural areas in the sub-Saharan Africa. The main crops grown in the state includes maize, yam, cassava, cocoyam, vegetables (such as okra, melon, tomato, and pepper), plantain, banana, cocoa, oil palm and rubber. Some of the inhabitants also engage in other incomegenerating activities like trading, processing, marketing of agricultural products and handicrafts.

\subsection{Population of the Study}

The population of the study includes all youth in Oyo State, Nigeria.

\subsection{Sample Procedure and Sample Size}

A multi-stage sampling procedure was used to select the sample for the study. In the first stage, three Agricultural Development Programme (ADP) zones (Afijio, Ogbomosho zone and Ibadan -Ibarapa) were randomly selected. The second stage involved randomly selecting one local government area from each of the three zones (Afijio, Ogbomosho and Ibarapa Central Local Government Areas respectively). The third stage involved the random selection of thirty participants in the Youth Empowerment Scheme from each of the three Local Government Areas chosen, thereby resulting in a sample size of 90 participants. For non-participants, the snowball sampling technique was used to select 30 respondents from the three Local Government Areas (Afijio, Ogbomosho and Ibarapa Central Local Government Areas respectively) making a total of 90 respondents. Therefore, the total sample size for the study was 180 .

\subsection{Data Analysis}

Frequency counts, percentages, mean and ranks were used to analyze the socio-economic characteristics of youth. Youth poverty status was determined using Community Based Targeting (CBT). CBT assessed the attributes of poverty from the youth perspective. After assessing the attributes of poverty, multidimensional poverty was used to ascertain the poverty status of the respondents. Poverty scores were computed for each respondent: high poverty scores indicated a low poverty status (better-off) while low poverty scores indicated high poverty status (poor). Respondents with poverty scores between 19-34 were considered poor; those with scores between 35-50 were considered average while those with scores between 51-66 were considered better-off. The t-test was used to compare the poverty status of participants with the poverty status of non-participants of the scheme.

\section{RESULTS AND DISCUSSION}

\subsection{Socioeconomic Characteristics of Youth}

Table 1 shows the socioeconomic characteristics of youth in the study area. The table reveals that $53.9 \%$ of the respondents were females while $46.1 \%$ were males. Over forty percent of the respondents (44.4\%) were aged 28-32 years, $25.6 \%$ were aged 23-27 years while $8.9 \%$ were within the age range of 18-22 years. Majority of the respondents $(63.3 \%)$ practiced Christianity and majority $(51.7 \%)$ were also married. The high percentage of married respondents suggests that marriage is a highly cherished social value. Table 1 also reveals that majority of the respondents $(97.2 \%)$ had formal education with only $2.8 \%$ of them without formal education. The finding agrees with Oyesola (2015) who reported that the level of formal education among residents of Oyo State is very high. The table also reveals that $75.6 \%$ of the respondents were engaged in various income-generating activities in the study area such as petty trading, engagement in civil service in the state, business, etc. The high level of engagement in 
these income-generating activities is a pointer to the unemployment situation of youth which compels them ${ }^{82}$ to be dependent on family members and friends economically (Ajufo, 2013 and Emeh, 2012). The findings corroborate Ejikeme (2014) who noted that unemployment in Nigeria affects job seekers within the ages of 20-44 years more than any other age group. Oduwole (2015) and Karim and Surajo (2016) pointed out that high level of unemployment is a major cause of youth poverty.

Table 1: Socioeconomic Characteristics of Youth in Oyo State.

\begin{tabular}{|c|c|c|c|}
\hline VARIABLES & FREQUENCY & PERCENTAGE & MEAN \\
\hline \multicolumn{4}{|l|}{ Sex } \\
\hline Male & 83 & 46.1 & \\
\hline Female & 97 & 53.9 & \\
\hline \multicolumn{4}{|l|}{ Age (years) } \\
\hline $18-22$ & 16 & 8.9 & \\
\hline $23-27$ & 46 & 25.6 & 29 \\
\hline $28-32$ & 80 & 44.4 & \\
\hline $33-37$ & 38 & 21.1 & \\
\hline \multicolumn{4}{|l|}{ Religion } \\
\hline Chrstianity & 114 & 63.3 & \\
\hline Islam & 60 & 33.3 & \\
\hline Traditional & 5 & 2.8 & \\
\hline Others & 1 & 0.6 & \\
\hline \multicolumn{4}{|l|}{ Marital status } \\
\hline Single & 81 & 45 & \\
\hline Married & 93 & 51.7 & \\
\hline Divorce & 4 & 2.2 & \\
\hline Separated & 1 & 0.6 & \\
\hline Widowed & 1 & 0.6 & \\
\hline \multicolumn{4}{|c|}{ Educational attainment } \\
\hline No formal Education & 5 & 2.8 & \\
\hline Primary education & 10 & 5.6 & \\
\hline Secondary education & 34 & 18.9 & \\
\hline NCE & 26 & 14.4 & \\
\hline OND & 44 & 24.4 & \\
\hline HND & 21 & 11.6 & \\
\hline Degree & 30 & 16.7 & \\
\hline Post-graduate & 10 & 5.8 & \\
\hline \multicolumn{4}{|c|}{ Income generating activities } \\
\hline Petty trading & 48 & 26.7 & \\
\hline Civil service & 40 & 22.2 & \\
\hline Business & 37 & 20.6 & \\
\hline Artisan & 6 & 3.3 & \\
\hline Farming & 3 & 2.8 & \\
\hline No activity & 3 & 24.4 & \\
\hline
\end{tabular}

Source: Authors computation

\subsection{Youth Poverty Status}

The mean poverty status score based on Community Based Targeting was 46.9 with 9.0 and 65.0 being the minimum and maximum poverty scores respectively. These poverty scores were used to group the respondents into three categories as follows: poor (19-34), average (35-50) and better-off (51-66). Table two reveals that $68.9 \%$ of participants of the Youth Empowerment Scheme were in the "average" category of poverty, 26.7\% were "better-off" while $4.4 \%$ were in the "poor" category. On the other hand, $52.2 \%$ of non-participants of the scheme were in the "average" category, $43.3 \%$ were in the "better-off" category while $4.4 \%$ were in the "poor" category. 
Table 2: Poverty category of youth in Oyo State.

\begin{tabular}{llll}
\hline Poverty Status & Participants & Non-participants & Total \\
& & & \\
\hline Poor (19-34) & $4(4.4)$ & $4(4.4)$ & $8(4.4 \%)$ \\
& & & \\
Average (35-50) & $62(68.9)$ & $47(52.2)$ & $109(60.6)$ \\
Better off(51-66) & $24(26.7)$ & $39(43.3)$ & $63(35 \%)$ \\
Total & $90(100)$ & $90(100)$ & $180(100 \%)$
\end{tabular}

Source: Authors computation

\subsection{Difference between poverty scores of participants in YES-O and non-participants}

The result in Table 3 shows that there is no significant difference between the poverty status of participants and the poverty status of non-participants in the Youth Empowerment Scheme of Oyo State at 5\% level of significance $(\mathrm{t}=0.99)$. The results contradict the findings of Fayemi (2012), Abdussalam (2015), Badejo, Agunyai and Adeyemi (2015) who reported that YES-O helped reduce poverty among youths. This contradiction could be due to the fact that a quality measure of poverty was used in this study which captured the attributes the respondents considered as indicators of poverty as opposed to other studies which measured poverty by different approaches. Furthermore, the finding could be attributed to certain constraints faced by the scheme as reported by Inyang and Asa (2020). These constraints include low monthly stipends, high transportation cost to the venue of the programme and inadequate monitoring and evaluation of the activities of the scheme.

Table 3: T-test showing difference in poverty status between participants and non-participants of Youth Empowerment Scheme in Oyo State.

\begin{tabular}{lllllll}
\hline Youth categories & $\mathrm{N}$ & $\begin{array}{l}\text { Mean } \\
\text { Score }\end{array}$ & $\mathrm{t}$ & $\mathrm{df}$ & P-value & Decision \\
\hline $\begin{array}{l}\text { Non-participants in } \\
\text { YES-O }\end{array}$ & 90 & 22.76 & 0.99 & 1.78 & 0.182 & Not significant \\
$\begin{array}{l}\text { Participants in } \\
\text { YES-O }\end{array}$ & 90 & 46.31 & & & & \\
\end{tabular}

Source: Authors computation 


\section{CONCLUSION}

The study ascertained the effect of the Youth Empowerment Scheme of Oyo State on the poverty status of youth in the State. The study revealed that the Youth Empowerment Scheme had no statistically significant effect on youth poverty in the state since no significant difference existed between the poverty status of participants and nonparticipants of the scheme. It can therefore be concluded that Youth Empowerment Scheme has failed to reduce the level of poverty among youth in Oyo State. It is therefore recommended that monthly stipends should be increased and there should be proper monitoring and evaluation of the activities of Youth Empowerment Scheme to ensure that the programme is realigned to meet its set objectives.

\section{REFERENCES}

Abdussalam, O. I. (2015). Impact of Youth Empowerment Scheme on Poverty alleviation in Nigeria, International Journal of Business, Economics and Law, 8(3): 35-39.

Ajufo, B. I. (2013) Challenges of Youth Unemployment in Nigeria: Effective Career Guidance as a Panacea, An International Multidisciplinary Journal Ethiopia, 7(1): 307-321.

Asa, U. A., Ekumankama, O. O., Ebong, E. O. and Uwem, C. A. (2007) Estimating the determinants of poverty among women farmers in Akwa Ibom State, Nigerian Journal of Agriculture, Food and Environment, 4(1-4): 22-26.

Canagarajah, S., and Thomas, S. (2002) Poverty in a Wealthy Economy: The case of Nigeria. International Monetary Fund Working Paper. July, 2002.

Badejo, B. T., Agunyai, S. C. and Adeyemi, O. O. (2015) Policy, Youth Recruitment and Empowerment in Nigeria: A case study of Osun State Youth Empowerment Scheme (OYES), Mediterraneen Journal of Social Sciences, 6 (1): 384-395.

Ejikeme J. N. (2014) Unemployment and Poverty in Nigeria: A link to National Insecurity, Global Journal of Politics and Law Research, 2 (1): 19-35.

Emeh, I. E. (2012) Tackling Youth Unemployment in Nigeria. The Lagos State Development and Empowerment Initiative. Afro Asian Journal of Social Science, 3 (3): 2229-5313.

Etuk, N. N. (2015) Effect of Youth Empowerment Scheme on Poverty Status of youth in Oyo State, Nigeria. M.Sc. Project, Department of Agricultural Extension and Rural Development. University of Ibadan, Ibadan.

Fayemi J. A. (2012) Youth Empowerment and Poverty alleviation. The experience in Nigeria's Ogun State, JORIND, 10(2).

Inyang, N. D. and Asa, U. A. (2020) Constraints to participation in Youth Empowerment Scheme of Oyo State. Nigeria, International Journal of Sociology and Anthropology Research, 6(1): 1-8.

Karim, A. H. and Surajo, A. Z. (2016) Youth unemployment and poverty in Nigeria: A threat to Sustainable Growth and Development, International Journal of Scientific Research and Scientific Studies, 4(11): 4919-4928.

Mazharul, H. K. and John, E. L. (2012). Microfinance, Poverty and Youth Unemplyment of Nigeria. A Review, Global Journal of Human Social Science Sociology, Economics and Political Science, 12(13): 45-59.

National Population Census (2006). Population and Housing Census of the Federal Republic of Nigeria. Analytical Report at the National Population Commission. Abuja, Nigeria.

Oduwole, T. A. (2015) Youth Unemployment and Poverty in Nigeria, European American Journal, 1:(2): 23-39.

Okafor, E. (2011). Youth Unemployment and Implications for Stability of Democracy in Nigeria, Journal of Sustainable Development in Africa. 13 (1): 358-373. 
Onuoha, C. F. (2007). Youth Unemployment and Poverty: Connections and Concerns for National Development in Nigeria, International Journal of Modern Political Economy, 1 (1):

Oyesola, O. B. and Ayinde, Y. O (2015). Socio-economic Status of households in University of Ibadan Social Laboratory in Igbo Ora, Oyo State, Nigeria, Nigerian Journal of Rural Sociology, 15(2): 95-101. 